\title{
5 The Western legal tradition and Soviet Russia
}

\author{
The genesis of H. J. Berman's \\ Law and Revolution
}

Adolfo Giuliani

\section{Introduction}

The Western legal tradition (henceforth WLT), a central presence in legal historiography following the immensely popular two volumes published by the Harvard legal historian Harold J. Berman Law and Revolution I: The Formation of the Western Legal Tradition (1983) and Law and Revolution II: The Impact of the Protestant Reformations on the Western Legal Tradition (2003), is in search of a precise definition.

This chapter traces the origin of this idea to the Cold War era. It shows that it was conceived by Berman in his 1950 book on Justice in Russia, a work in which he wanted to explain to a Western audience what lay beyond the Iron Curtain. To this purpose, he constructed an account in which he placed the West and Soviet Russia in opposition and concluded that they were made of the features that were missing in each other. A chapter in that book is the blueprint for his two well-known volumes on Law and Revolution published in 1983 and 2003 (and for a third volume left unfinished).

The WLT grew from another legacy received from the Cold War era: human rights history. Recent scholarship tells us that this theme attracted scholarly attention beginning from the 1970s following contemporary concerns with human rights in Eastern European countries. This chapter shows how this theme was absorbed by WLT by hijacking a core component of continental legal science (subjectives Recht), then re-engineered by political theorists into the major identitary element of the WLT in an eternity history rooted in medieval canon law.

\section{Harold J. Berman and the construction of the Western legal tradition}

When legal scholars speak of the WLT, we swiftly understand what they mean. This expression belongs to common parlance and is a useful and quick shorthand to summarise a host of ideas immediately labelled with a precise identity. It only works, however, at a general level. As soon as we begin to see it more closely and wonder for instance about its content and geographic boundaries, we realise 
we are facing difficult questions, and we soon understand that this successful phrase is relying more on an instinctive or even emotional appeal than on a rational basis.

The only way to dispel the uncertainty over the WLT is to analyse it historically and tackle the questions which a historian would typically ask: where does this expression come from, who introduced it, for what purposes, who were her audience, and what did she want to do by using this expression? These are the questions this chapter aims to answer. This is not difficult, as the author who introduced this expression and, by placing it at the heart of one of the most successful legal-historical accounts published in the 20th century, gave it the broadest dissemination, is well known: the American legal historian Harold J. Berman (1918-2007). Berman offered a grandiose account of the growth of a WLT in his two monumental volumes, Law and Revolution I: The Formation of the Western Legal Tradition (1983) and Law and Revolution II: The Impact of the Protestant Reformations on the Western Legal Tradition (2003). Less known is the overall project, left unfinished, and even less its original purpose. In spite of the attention it attracted, it has been left unnoticed that this overwhelming project was first conceived as part of his book Justice in Russia: An Interpretation of Soviet Law, published in 1950.

This chapter goes back to this project's formative stage, offering an essay in the history of legal history. At its heart is a question about the historical consciousness of legal history because one of the features of this discipline is that of having forgotten how deeply the categories with which legal historians think and write about the legal past are embedded in ideas rooted in the 20th century.

My purpose in what follows will be to explain the rise of the WLT focusing on three points: (1) to show how Berman's idea of a WLT arises from his 1950 book Justice in Russia and that the idea is a mirror-image of another projection: the legal tradition of Soviet Russia; (2) to show the philosophical premise upon which his historical project is based, to be found in his university mentor Eugen RosenstockHuessy; and (3) to demonstrate the question of human rights history is the main building block of the WLT and, further, that in building that account, the idea of the 'Eastern tradition' without human rights served as a convenient context.

\section{Harold J. Berman's Justice in Russia (1950)}

The American legal historian Harold J. Berman is unquestionably one of the major contributors to 20th century legal history. His two massive volumes, Law and Revolution I (1983) and Law and Revolution II (2003), redirected this discipline with his compelling thesis about legal evolution. He suggested that “the Western legal tradition was born out of a 'revolution' and thereafter, during the course of many centuries, has been periodically interrupted and transformed by revolutions" (Berman, 1983, p. 1).

This thesis is fleshed out in a rich account branched out in many fields and developed in significant detail through a long temporal arch. Its influence has 
been considerable; it has received appraisals and fostered countless debates (Duve, 2013). It is true that matters of detail have attracted the attention of his critics, but its chief contribution is not in particular aspects of the many fields touched upon, mostly drawn from secondary sources, but in the broad evolutionary hypothesis that as a vestment clothes his narrative. The powerful message brought forward by his evolutionary account is an auto-representation of the Western identity.

We would not understand his project, however, without knowing its origin. It was in fact conceived in his book Justice in Russia (1950) and presented in a chapter (Ch. 6: 'The Western Legal Tradition') in which we find the major thesis of a legal evolution through successive revolutions. This is the blueprint of his lifelong project, which he then developed in Law and Revolution I (Berman, 1983) focused on the Papal Revolution; then carried forward in his Law and Revolution II (Berman, 2003) on the German and English Revolution; and was meant to be continued, as we learn from John Witte, in a further volume on the American, French and Russian revolutions, which, however, remained unfinished as a result of his untimely death (Witte, 2014, p. 146). The overall project is summarised in the following table that ends the chapter (Berman, 1950", p. 121).

Berman's Justice in Russia: An Interpretation of Soviet Law (1st ed. 1950; 2nd ed. 1963: Justice in USSR: An Interpretation of Soviet Law) was written to offer a key to make sense of Soviet Russia. During the Iron Curtain era, Soviet Russia was beyond the reach of Westerners: mysterious, distant as an ancient civilisation, and felt to be in dramatic opposition to the West. More than a doctrinal analysis of the laws and institutions of the Soviet system, Berman's purpose was to illustrate Russian life as

\begin{tabular}{|l|l|l|l|l|}
\hline Year & Revolution & Law movement & $\begin{array}{l}\text { Constitutional } \\
\text { principles }\end{array}$ & $\begin{array}{l}\text { Private-law } \\
\text { contributions }\end{array}$ \\
\hline 1075 & Papal revolution & $\begin{array}{l}\text { Renovation of Roman } \\
\text { and Canon law }\end{array}$ & $\begin{array}{l}\text { Visible, hierarchical, } \\
\text { legal church; } \\
\text { separation of church } \\
\text { and state. }\end{array}$ & $\begin{array}{l}\text { Principles of Reason, } \\
\text { Conscience, and } \\
\text { Precedents. }\end{array}$ \\
\hline 1517 & $\begin{array}{l}\text { German } \\
\text { reformation }\end{array}$ & $\begin{array}{l}\text { Reception of Roman } \\
\text { law }\end{array}$ & $\begin{array}{l}\text { Absolute monarchy: } \\
\text { secular civil service } \\
\text { (Bureaucratic, Rational } \\
\text { State) }\end{array}$ & $\begin{array}{l}\text { Freedom of contract, } \\
\text { freedom of wills; } \\
\text { conceptualist law }\end{array}$ \\
\hline 1640 & $\begin{array}{l}\text { English } \\
\text { Revolution }\end{array}$ & $\begin{array}{l}\text { Restoration of } \\
\text { Common law }\end{array}$ & $\begin{array}{l}\text { Parliamentary system; } \\
\text { landed aristocracy; } \\
\text { judiciary independent } \\
\text { of politics. }\end{array}$ & $\begin{array}{l}\text { Family settlements; } \\
\text { feudal property } \\
\text { without feudalism; } \\
\text { traditionalist law. }\end{array}$ \\
\hline \multirow{3}{*}{1789} & $\begin{array}{l}\text { French } \\
\text { Revolution }\end{array}$ & Napoleonic codes & $\begin{array}{l}\text { Individualist } \\
\text { democracy; separation } \\
\text { of powers; government } \\
\text { by public opinion. }\end{array}$ & $\begin{array}{l}\text { Absolute private } \\
\text { property conceived in } \\
\text { contractual terms; } \\
\text { contractualist law. }\end{array}$ \\
\hline
\end{tabular}

Figure 5.1 The Western legal tradition. 
reflected in legal materials. The work was about 'justice' in Russia, purposefully addressed to explaining the sense of right and wrong and the broad principles that structured Soviet society.

If the purpose is to understand Soviet life, Berman tells us, we need legal history. It would be misleading, he continues, to focus on socialist theory only: we should turn to the intellectual forces that, more powerfully than theories, shape human societies, their laws and institutions. The key to explain that legal world is in a historical account of the legal past. He also adds that Soviet legal scholars have been conscious of their Russian heritage: they were aware not only of Marx and Engels, Lenin and Stalin, but for the purposes of continuity and stability they also turned to pre-Revolutionary Russia (Berman, 1950, Ch. 4, Marxism and the Russian Heritage). Soviet leaders therefore broadened legal education to include Russian legal history and Latin to understand Roman law, in which Russia imagined her roots. Westerners, however, have no hope of understanding Russian legal history in its own terms; they must first turn to their own Western legal tradition because of 'the polarity that has existed between Russian history and Western legal history for almost a thousand years' (Berman, 1950, p. 110). The Russian tradition was autonomous, unrelated to the common tradition that united the various systems of the West.

The major interest for us in his Justice in Russia is Chapter 6 on the WLT. Those who are familiar with his later big volumes will be surprised by the dazzling speed with which Berman deals with his topic. They may also notice some rather unexpected statements, such as the notion that the German Reformation (the second revolution according to Berman's plan) occurs at the same time as the reception of Roman law (bringing it forward a century), though this suggestion is then corrected in the later volumes. Another feature is the inclination for macro-structures. We learn that the Western legal tradition is set in motion by

[...] three leading principles: the principle of Reason, the principle of Conscience, and the principle of Precedents [...] and the ideas associated with them of the supremacy and completeness of law, the equality of law, and the growth of law [...] [which] remain the foundation of the legal system of every Western people.

To this, Berman quickly adds:

It is more than mere coincidence that only now, with the collapse of the European system of national states and the rise to power of Russia [...] we are able to rediscover the unity and continuity of the Western legal tradition which modern nationalisms have for so long observed. (Berman, 1950, p. 121)

The main purpose was not to define a legal tradition perceptible as Western but to make sense of the political world that lay on the other side of the Iron Curtain. In Berman's account, the West and Soviet Russia are in diametrical opposition 


\section{2}

and hence define each other. Thus, those features that produced Western legal evolution are those Russia lacked, and their absence explained the special features of Soviet law.

It would be misleading to look at Berman's book without keeping in mind how powerfully the divide between the West and the East lurked in the background. Berman's thesis about the WLT arose from a storage of memories whose dominant note was fear-fear about the polarity between Soviet Russia and the West, about nuclear destruction, about further military expansion towards the West and the expansion of Communism in the West. Berman tells us of Lenin's theory of a 'contest of two systems': 'in which West and East could survive alongside, but without ceasing to determine the class struggle' (Charter 77,1977, p. 119). Such fears materialised in the image of an Iron Curtain, an image that gave free rein to imagined threats and to an opposition in which Eastern Europe was invented as an intellectually and culturally separate land (Judt, 1990).

Berman's book tells us that East and West were also separated juristically in that they belonged to different legal traditions. In this sense, the Iron Curtain influenced the formation of the WLT. It gave rise to a narrative written in reaction to a very different post-war world in which Westerners saw Easterners as their opposite and designed a Western legal identity in contrast to the Eastern. This Western identity arose from the acceptance of some fundamental principles that were supposedly lacking in Soviet Russia-among which were the rule of law, human rights and private property. These principles acquired an unquestionable authority by being carried over from generation to generation by tradition, which leads us to a natural question, what do we mean by 'tradition'?

\section{Rosenstock-Huessy: An outsider ahead of his time}

The essence of Berman's project is in the two words 'tradition' and 'revolution' in his title Law and Revolution I. The Formation of the Western legal tradition (1983) and Law and Revolution II: The Impact of the Protestant Reformations on the Western Legal Tradition (2003). They mean first that legal rules must be understood as a tradition and, second, that they change in time according to a pattern punctuated by successive revolutions.

This simple idea risks being misunderstood if one is not aware of its philosophical basis, which is to be found in an important and original book, Out of Revolution: Autobiography of Western Man, first published in 1938 by Berman's former university mentor Eugen Rosenstock-Huessy (1888-1973). This book dismissed the conventional academic historiography practised in Germany and generally followed in European universities (Iggers, 2012). This book indicated another and captivating approach towards the past consciously based on an original philosophical foundation. The aim was to revitalise the vital link of history and memory.

Eugen Rosenstock-Huessy was a learned and highly original German scholar who emigrated to the United States in 1933. He first taught at Harvard and then 
at Dartmouth, where Berman was among his students. He is remembered as a compelling teacher and pioneering mind who paid the price for his originality by being ignored by academia, as he notes in a sombre conclusive note to his Out of Revolution (1938). Today we know Rosenstock through Berman, who refers admiringly to him in the introduction to his own Law and Revolution I (1983) and in a substantial introduction to Rosenstock's Out of Revolution. Out of Revolution was ahead of its time: first, because its interdisciplinary approach aimed at bringing to light the collective memory of the legal past explained through law, theology, natural sciences, linguistics and even cartography and numismatics. Second, its historical narrative goes backwards: because it is meant to explain the intellectual identity of his generation, it begins from the present time moving towards the past through successive revolutions, beginning from the Russian Revolution down to the French, English, German and Papal revolutions. Third, the connective theme of his book, tradition, at that time was unconventional. Those who read Out of Revolution: Autobiography of Western Man as a sharp turn away from conventional academic history were unquestionably correct.

In Out of Revolution, Rosenstock-Huessy wanted to offer not only an account of European history but also a theory of history: he had a compelling view about how history should be understood and made (Rosenstock-Huessy, 1938, p. 692). There are two approaches to the past, he argued: one is history, understood as the academic discipline taught and practised in German universities, and the other is memory. This distinction is at the heart of his own attempt to capture a viable identity for his generation. It required two bold steps: first, to reject the philosophical basis (Cartesian rationalism) upon which the history he criticised rested and, second, to seek another approach to understand the past based on memory and tradition.

In this context should be placed the rise of interest for legal tradition as an explanatory concept. While today this is one of the standard concepts of legalhistorical research (Glenn, 2014), the idea of a legal tradition in its progress toward acceptance has meant another explanation of law creation that replaced the legislative-based idea of sources of law. They are two competing explanations of how legal rules come into being, and references to legal traditions surged when the sources of law started to be examined critically as an insufficient and doubtful explanation of law creation (Calasso, 1954; Jestaz, 2015).

Rosenstock-Huessy's major appeal is in a philosophy of history aimed at understanding and explaining the Western identity. What is the leading force in its evolution? How does one explain legal change? Rosenstock replies that the game changers are critical moments that impact the human world at its various levels (social, economic, legal), and a feature of European history is the number and intensity of those turning points. They are waves of changes that invested different countries at different times: Bolsheviks in Russia, Jacobins in France, Cromwell in England, Luther in Germany, popes in Italy. They are the generative forces that recurrently occur, forwarding evolution to the next step.

Rosenstock-Huessy's revolutions cannot be separated from his account of memory and tradition. In his going backwards from the present to the past, he 


\section{Adolfo Giuliani}

sees the linearity of time interrupted by crises that are harbingers of new forms of consciousness and new ways of thinking and living, then made perceptible in new institutions, language modifications, new conceptualisations of time and representation of space or of reasoning. Revolutions produce semantic shifts and new vocabularies. Humans modify and reformulate their language: they are name-giving animals who construct their world making use of language: 'Our passions give life to the world, our collective passions constitute the history of mankind' (Rosenstock-Huessy, 1938, p. 3). They arise from a storage of collective memories, as it were. They re-semaniticise their environment, redirecting the impulses that govern the flow of information. At the same time, they create a web of interactions between present and past in a chain of responses and dialogues from which the European tradition is made.

Along with tradition, the other interface between Rosenstock-Huessy and Berman is the reference to revolutions. In Berman, however, the sequence is turned upside down. While Rosenstock-Huessy moves backwards from the Soviet Revolution to the medieval Papal Revolution, Berman goes forward: his account of the WLT begins from the Papal Revolution of the period 1050-1200. This phase is the one that has attracted the greatest attention by far. His thesis focuses on the 'revolutionary' impact of the period 1050-1200, which he presents as the time that produced the deepest transformations in the legal world. The bishops of Rome claimed control over the Church, and their newly acquired autonomy from secular powers transformed the legal world. It reformulated legal thinking, giving rise to coherent bodies of laws and legal studies whose major fruit was the learned legal science of canon and civil law. Berman's thesis was original. Departing from the Romanists' orthodoxy, and particularly from Koschaker, the focus shifted from Roman to canon law. It is therefore from religion and canon law that the WLT found its beginning. This argument then expanded by including the dissemination of canon law on a European scale that included English law (Helmholz, 1996). By turning to canon law, Berman broadened legal-historical studies to the interplay between the religious and secular component of the law, giving life to the most fruitful stream of research (Prodi, 2000; Decock, 2013; Gordley, 2006). Yet in the context of this volume, it is notable that Berman's approach to legal history was initiated by a comparison with the East and the West. As Berman himself wrote in Justice in the USSR:

Russian law, therefore, challenges us to rediscover the unity and continuity of the Western legal tradition [...] to find the link between the politicallegal and the moral-spiritual aspects of our own heritage. (Berman, 1963, pp. 268-269)

\section{The Western legal tradition and natural rights history}

The period between Berman's early formulation of the Western legal tradition in his 1950 book Justice in Russia and the immensely successful 1983 volume 
Law and Revolution saw the formula of WLT acquiring currency in a bipolar world locked in the strident rivalry between the Soviet bloc and Western countries. The WLT represented the West in its essential traits in a way that summarised both its identity and emblematically its success in the ideological battleground. Of the many themes that made up the WLT, the most compelling was that of human rights history, according to a formula that condensed the essence of Western identity in a way that transcended earlier references to rights tout court, natural rights and the rights of man.

Samuel Moyn made a case to show how this was a powerful inspirational concept that entered political language with a universal ring and was soon absorbed into political consciousness as a centrepiece of political language (Moyn, 2011). It spoke of a natural freedom possessed by individuals who were members of a moral community of universal nature irrespective of state boundaries. Whereas the Truman Doctrine (1947) addressed people with a choice 'between alternative ways of life'-freedom or oppression, control, and terror-human rights presented a cosmopolitan vision of a universal humanity, the fruit of an immemorial inheritance grown into maturity at a time of stark political confrontation. In the latter stages of the Cold War, human rights became a veritable cult object. 'America did not invent human rights,' asserted President Jimmy Carter in 1981, '[i]n a very real sense, it is the other way round. Human rights invented America' (Moyn, 2014, p. XIV). During the bipolar stalemate of the Cold War, human rights functioned to identify the moral community that Soviet Russia threatened. If in the West they were vital, their absence in the East signalled the perceived failure of the Soviet bloc (Moyn, 2014, p. XIX). This was one of the chief features that supposedly distinguished the West from Soviet Russia. If human rights made America, their absence made Soviet Russia.

The heated political atmosphere coincided with Berman's elaboration of his thesis about the WLT. As the bipolar mentality of the 1950s had led Berman to formulate this notion as a mirror image of the legal tradition of the Soviet Russia, his pioneering work inspired a multitude of studies that further derived from that fundamental distinction between the East and the West in their attempt to depict the past of the contemporary (and politically loaded) dilemmas. From the 1980s, the idea of WLT rose to become a prominent field in its own right. Like a magnet, it attracted diverse themes that were only briefly outlined in Berman's book. Filling these slots, other scholars supplemented the original narrative with additional argumentative blocks, making the concept broader, more persuasive and electrifying. One of these expansions was natural rights history.

What was almost entirely missing from the legal-historical scholarship of 1980s was some clarity about the origin of rights: in academic research, it was terra incognita. ${ }^{1}$ Yet this was about to change, and in the consequent debate on the natural rights history, the idea of WLT played a significant role by providing the strongest possible basis. Few arguments have more impact than a creation in immemorial time and an eternal history that has been with us forever.

In 1988 a Festschrift was published to celebrate Harold J. Berman (The Weightier Matters of the Law: A Tribute to Harold Berman). It opened with an 
essay 'Villey, Ockham and the Origin of Individual Rights' by the BritishAmerican legal historian Brian Tierney (1922-2019), which soon became the most cited article in the new field of rights history (Tierney, 1988). The real question, according to Tierney, was about 'the origin of Western rights theories.' By saying this, he manifested his preoccupation not with their essence, but with their genesis, which had to be reformulated. Rights were qualified by various adjectives (individual, subjective, natural, and modern), but the one that counted most was to be 'Western' (Tierney, 1988, p. 13).

Although indicated with a vague denomination, the concept which Tierney's article borrowed from Continental law was extremely precise-droit subjectif, diritto soggettivo, Subjectives Recht. In moving from the continent to the new Anglo-American home, it acquired some additional features. The first was to be presented as the winning argument that defeated the French Romanist and philosopher Michel Villey. No effort was spared by Tierney in his piece to annihilate his adversary. As a result, covered by a veil of oblivion, Villey was then accurately cited in the ensuing deluge of studies only to remember his defeat in that memorable dialectical duel. But to be fair, Tierney and Villey were talking about different things: Tierney's focus was the 'origin of Western right theories' (Tierney, 1988, p. 13), while Villey's was the 'origin of droit subjectif' (genèse $d u$ droit subjectif), an expression untranslatable in English for the lack of a corresponding concept. They were talking from different disciplines (political theory and law); for different purposes (Villey explaining a technical component of continental legal systems, Tierney building the core of the WLT); and in different languages (English and French).

Michel Villey (1914-1988) belongs to the group of jurists who wanted to reformulate the 19th century intellectual legacy received from the theory-centred and hugely influential strand of German legal science, Pandectism. He sought to enlarge what he perceived to be a field impoverished by the demise of justice, which he believed to be intrinsic to legal science, but at the same time he shared the preoccupation of his generation to separate the legal from the interference of politics, religion and morality. At the heart of Pandectist systems bequeathed to 20th century legal science, he saw a foundational idea: droit subjectif.

The Roman law-based legal systems of continental Europe are designed to begin from a basic unit indicated as droit subjectif. This notion serves the following purposes. The first function is explanatory: it explains how individuals can create effects in law. Broadly speaking, why is a contract binding (and by analogy, a law, a sentence, an administrative act), and why does it create obligations? The droit subjectif doctrine answers by imagining an individual who exerts will. The main idea is that individuals possess an inner power that produces effects of juristic relevance. The second purpose is constructive: the creative power in the individual is the starting point for designing the legal system conceptually. This idea is deemed to belong to the essentials of continental legal science, and it has been minutely analysed by an immense mass of scholarship and brought to a considerable degree of sophistication by 19th century Pandectism. ${ }^{2}$ 
Villey wanted to deactivate the bewitching power of droit subjectif by analysing it historically. He looked at the Pandectist constructions of Savigny, Puchta and Windscheid searching for their philosophical foundations. He noted that behind those constructions, whose source was usually attributed to Grotius, was a specific philosophy arising from medieval nominalism and suggested that the primary contributor was the logician William of Ockham.

The fundamental objection posed by Villey was to denounce that these 19th century constructions were the fruit of philosophical theories based on the view of an abstract individual. They produced systems of droits subjectifs (with its corollaries of absolute property, real rights and will theories) and created legal institutions whose starting point was an abstract individual, not the many communities in which humans effectively lead their lives, from the family to the natural environment. Secondly, such theories, operating at such a level of abstraction, produced a sort of legal thinking that expelled justice from the scope of jurisprudence. Its ultimate fruits were lists of human rights, comforting declarations of good intentions but no more effective than noble and illusionary dreams. ${ }^{3}$

In his article, Tierney wanted to take the first and important step in the direction of natural rights history. However, instead of beginning with a clean slate, he thought to begin by launching an attack on Villey's thesis about the origin of the droit subjectif. He was disturbed by the suggestion that droits subjectifs could be the fruit of the voluntarism and individualism brought about by the resurgence of nominalism between the 16th and 17th centuries. ${ }^{4}$ His article endeavoured to antedate the origin to the Papal Revolution of the 12th century, and here he leaned on Berman's account of WLT. As Berman put it:

Maitland called the twelfth century 'a legal century.' It was more than that: it was the legal century, the century in which the Western legal tradition was formed. (Berman, 1983, p. 120)

One of the features of the 12th-century Renaissance, according to Berman, was that canon law writings 'permeated the doctrines based on individual intentions and individual will in areas like the law of torts, the law of contract, the law of marriage' (Tierney, 1988, p. 135). Prudence would have advised clarifying what the phrase 'doctrines based on individual intentions and individual will' meant, but to Tierney that phase seemed the ideal seedbed to nurture the rise of rights doctrines:

The doctrine of individual rights was not a late medieval aberration from an earlier tradition of objective right or of natural moral law. Still less was it a seventeenth-century invention of Suarez or Hobbes or Locke. Rather, it was a characteristic product of the great age of creative jurisprudence that, in the twelfth and thirteenth centuries, established the foundations of the Western legal tradition. (Tierney, 1988, p. 31)

Tierney's attack on Villey's theory (and on the idea that the origin of natural rights was Ockham's philosophy) was fierce-and questionable. ${ }^{5}$ The major doubt about 
the method followed by Tierney is his confidence in relying on a limited set of texts to demonstrate such a far-reaching theory as individual rights. Those texts are in fact a necessary but not sufficient condition. Texts are one element in a broader institutional architecture in which questions of philology, interpretation and hierarchical structure determine their effective application. Tierney was in fact correct in spotting the difference that divided him from Villey:

$[\mathrm{H}]$ is [Villey's] prior conviction [was] that major shifts in legal and political ideas could occur only after an appropriate pattern of thought had been created in the sphere of pure philosophy. (Tierney, 1988, p. 20).

Legal science operates indeed by proceeding conceptually according to changeable philosophical models embedded in a plurality of philosophical dimensions. It would therefore be misleading to separate law from the dominant philosophies, for example to separate the pre-1650 period from Scholasticism, the following period from Rationalism, the 19th century from Kant, the 20 th century from linguistic philosophies, and the 21 st century perhaps from the philosophy of information.

Another observation is that the shift from droit subjectif to natural rights history in the 1980s signalled the regression of legal science's boundaries. Droit subjectif, a topic originally at the heart of continental legal science, was captured by political theorists, translated into a cluster of denominations (individual, subjective, natural, modern, Western) and its origins reengineered into an eternity history that ironed out the recurrent shifts in philosophical, and hence legal, thinking. It is perhaps the case that another shift has occurred, by which the self-congratulatory account of a rise of the WLT in a direct line of development that indicates both the mythical origin and the way ahead, has lost its original appeal. As we learn from recent scholarship, human rights history entered political debates in the 1970s, and it arrived, as Moyn suggests, with 'a recognizably utopian program: for the political standards it champions and the emotional passion it inspires' (Moyn, 2011, p. 1).

\section{Conclusion: the WLT and the Cold War}

The Western legal tradition arises from the Cold War. Conceived by the Harvard legal historian Harold J. Berman in a chapter of his 1950 book on Justice in Russia, and then developed in his well-known 1983 and 2003 volumes (and in a third left unfinished), since then this idea has been a staple concept to make sense of the legal past.

In his Justice in Russia, Berman wanted to explain to a Western audience what lay beyond the Iron Curtain. He constructed his idea of WLT in an account set out in opposition in which the West and Soviet Russia define each other in a mirror image. The WLT's almost ubiquitous currency grew from another legacy from the Cold War era: human rights history. This chapter shows how the WLT absorbed this theme, hijacking a core component of continental legal science 
(droit subjectif) reengineered by political theorists into the major identitary element of the WLT in an eternity history rooted in medieval canon law. Paradoxically, natural rights history was further used in depicting a future in which the world would be something that the East was not.

The chapter addresses the question of the historical consciousness of legal history. One of the features of this discipline is that of having forgotten how deeply the language with which legal historians think and write about the legal past is embedded in ideas rooted in the 20th century. This chapter has attempted to look back at those times and to bring to light those ideals and hopes that legal scholars invested in the project of the WLT. It also recognises how much of that project was the fruit of the fear that marked the bipolar standoff of the Cold War, which today we can still glean from Harold J. Berman's works written at that time.

My purpose was not to offer an argument about the historical relativism of WLT's identitary narrative. I rather believe that making explicit its formation and attempting to understand the role it served then is a necessary step to figuring out how it can be transcended.

\section{Notes}

1 In the 1970s, human rights history was a minor field without adherents or audience. To have an idea of the state of the art in this field we must turn to a bibliography 'On the Nature and Foundations of Rights, 1947-77,' published by the journal Political Theory in 1978. It was limited in size (comparable to the bibliography on Hobbes studies in the German language published during 1968-1981) and was only partially focused on human rights specifically (the requirement for a research field is agreement on the subject matter). It is also worth mentioning that in British universities in the 1970s, human rights were taught as one among other rights traditions: one was Utilitarianism, centred on Bentham, who described rights as 'nonsense upon stilts,' while other rights traditions at that time included J. S. Mill, Isaiah Berlin and Michael Oakeshott (Gray, 2011). Universalism was not necessarily connected with rights. As Moyn wrote, '[a] universalism based on international rights could count as only one among others in world history' (Moyn, 2011, p. 13).

2 Briefly, a definition: the Pandectist Georg Friedrich Puchta (1798-1846) in his Lebrbuch der Pandekten defined 'Recht in subjectiven Sinne' as follows: 'A right (according to a subjective meaning) is present if an object is given in the Power of a Person by the right (according to an objective meaning)' (ein Recht (im subjectiven Sinne) ist vorbanden, wenn ein Gegenstand durch das Recht (in objectiven Sinne) in die Macht eitner Persongegeben ist.) (Puchta, 1838, p. 30). The adjective 'subjective' is a legacy of 18 th century Scholastic Latin: 'subjective' is the attribute to the subject and belongs to its essence, as explained in a standard logic textbook published by Isaac Watts in 1725 (Logick, II, ii, $\$$. 8): 'Objective certainty, is when the proposition is certainly true in itself; and subjective, when we are certain of the truth of it. The one is in things, the other is in our minds.'

3 As we have learned from recent scholarship, the recognition of humanity is not guaranteed by being inserted into lists of human rights (Moyn, 2011; Douzinas, 2000, p. 372).

4 'Seventeenth century thinkers $[\ldots]$ were influenced not only by the circumstances of their own age but also by an earlier tradition of thought they had inherited' (Tierney, 1989, p. 623). 


\section{0}

5 The stringent voluntarism upon which Ockham framed his natural law was one of the intellectual forms used by 16th-17th century jurists in their thinking, and their source was Ockham (Vazquez, Suarez). Moreover, the linguistic philosophy that complemented that voluntarism to justify the binding power of human will was nominalism, and again their source was Ockham. It is also true that in some medieval texts we can read 'ius' and 'habere ius,' but they do not demonstrate a theory of right. 'Ius' is a slippery term. Still in late 16th century university teaching, students were taught the 36 meanings of the word 'ius' (Bolognetti, 1551). On the other hand, 'habere ius' means several things, one of which is to share a greater good, and even today in neo-Latin languages we have the notion of 'avere ragione,' 'tener razon,' 'avoir raison' (to 'hold' or 'have' reason). In Rome, the 'habere ius' of one who has committed parricide was the right to be thrown into the River Tiber in a bag filled with vipers. Other texts presented by Tierney are equally questionable. He observes that the divine commandment 'Honour thy father and mother' can be rephrased by saying that 'parents have a right to the respect of their children' (Tierney, 1988, p. 33), which is simply a conjecture that has been pushed too far.

\section{References}

Assmann, J. (1992) Das Kulturelle Gedächtnis: Schrift, Erinnerung und Politische Identität in früben Hochkulturen, Munich: Verlag C. H. Beck.

Berman, H. J. (1963) Justice in the USSR: An Interpretation of Soviet Law (rev. ed.), Cambridge (Mass.): Harvard University Press.

Berman, H. J. (1950) Justice in Russia: An Interpretation of Soviet Law, Cambridge, (Mass.): Harvard University Press.

Berman, H. J. (1983) Law and Revolution I: The Formation of the Western Legal Tradition, Cambridge and London: Harvard University Press.

Berman, H. J. (2003) Law and Revolution II: The Impact of the Protestant Reformations on the Western Legal Tradition, Cambridge: Harvard University Press. Bolognetti, G. (1551) Tractatus de differentia iuris et facti, Napoli.

Calasso, F. (1954) Medioevo del diritto, Vol I, Le Fonti. T. 1, Milano: Giuffrè.

Charter 77 (1977) White paper on Czechoslovakia, International Committee for the Support of Charter 77 in Czechoslovakia, Paris.

Decock, W. (2013) Theologians and Contract Law: The Moral Transformation of the Ius Commune (ca. 1500-1650), Leiden and Boston: Martinus Nijhoff. DOI: 10. $1163 / 9789004232853$.

Douzinas, C. (2000) The End of Human Rights: Critical Thought at the Turn of the Century, Oxford and Portland: Hart Publishing.

Dummett, M. (1994) 'Testimony and Memory', in Matilal B. K. and Chakrabarti (eds) Knowing from Words. Western and Indian Philosophical Analysis of Understanding and Testimony, Dordrecht: Springer, 251-272. DOI: 10.1007/ 978-94-017-2018-2.

Duve, T. (ed.) (2013) 'Law and Revolution-Revisited', Rechtsgeschichte - Legal History 2013, no. 21: 156-159. DOI: 10.12946/rg21/156-159.

Giaro, T. (2013) 'The East of the West. Harold J. Berman and Eastern Europe', Rechtsgeschichte, 21, 193-197. DOI: 10.12946/rg21/193-197.

Glenn, H. P. (2014) Legal Traditions of the World: Sustainable Diversity in Law, Oxford: Oxford University Press. DOI: 10.1093/he/9780199669837.001.0001. 
Gordley, J. (2006) Foundations of Private Law: Property, Tort, Contract, Unjust Enrichment, New York: Oxford University Press.

Halbwachs, M. (1992) On Collective Memory, in Coser L. A. (ed), Chicago and London: University of Chicago Press.

Helmholz, R. H. (1996) 'The character of the western legal tradition. Assessing Harold Berman's contributions to legal history', in Hunter H. O. (ed), The Integrative Jurisprudence of Harold J. Berman, Boulder and Oxford: Westview Press, 29-50.

Iggers, G. G. (2012) The German Conception of History: The National Tradition of Historical Thought from Herder to the Present, Middletown: Wesleyan University Press. Jestaz, P. (2015) Les Sources Du Droit, Paris: Dalloz.

Judt, T. (1990) 'The Rediscovery of Central Europe', Daedalus, 119:1, 23-54.

Koselleck R. (1985) Futures Past, Cambridge (Mass.): Massachusetts Institute of Technology Press.

Maritain, J. (1922) Antimoderne, Paris: Édition de la Revue des jeunes.

Moyn, S. (2011) The Last Utopia: Human Rights in History, Cambridge (Mass.): Harvard University Press. DOI: 10.2307/j.ctvjk2vkf.

Moyn, S. (2014) Human Rights and the Uses of History, London and New York: Verso.

Prodi, P. (2000) Una storia della giustizia. Dal pluralismo dei fori al moderno dualismo tra coscienza e diritto, Bologna: Il Mulino.

Puchta, G. F. (1838) Lehrbuch der Pandekten, Leipzig: Barth.

Rosenstock-Huessy E. (1938) Out of Revolution: Autobiography of Western Man, New York: Morrow and Co.

Rosenstock-Huessy E. (1970) Speech and Reality, Norwich: VT Argo Books.

Tierney, B. (1988) 'Villey, Ockham and the Origin of Individual Rights', in Witte, J. and Alexander, F. S. (eds) The Weightier Matters of the Law: Essays on Law and Religion; a Tribute to Harold J. Berman, Atlanta: Scholars Press, 1-31.

Tierney, B. (1989) 'Origins of Natural Rights Language: Texts and Contexts, 1150-1250', History of Political Thought, 10:4, 615-646.

Villey, M. (1983) Le droit et les droits de l'homme, Paris: PUF.

Witte, J. and Alexander, F. S. (eds) (1988) The Weightier Matters of the Law: Essays on Law and Religion; a Tribute to Harold J. Berman, Atlanta: Scholars Press.

Witte, J. and Manzer, C. J. (2014) 'A Prequel to Law and Revolution: A Long Lost Manuscript of Harold J. Berman Comes to Light', Journal of Law and Religion, 29, no. 1, 142-169. DOI: 10.1017/jlr.2013.3. 